\title{
ENVIRONMENTAL ADAPTATION OF THE SOURCE OF THE SUBBASIN OF RICO STREAM, MONTE ALTO - SP, BRAZIL
}

\author{
TERESA C. T. PISSARRA ${ }^{1}$, ALINE B. MARCUSSI ${ }^{2}$, GILBERTO DA R. LEÃO ${ }^{3}$, \\ JOÃO A. GALBIATTI ${ }^{4}$, MAURICIO J. BORGES ${ }^{5}$, SERGIO CAMPOS ${ }^{6}$
}

\begin{abstract}
The aim of this study was to define the photographic patterns that represent the use and occupation of the landcover of the "spring" of the Rico Stream subbasin, located at Monte Alto, state of São Paulo (SP), Brazil, for environmental adaptation regarding the Brazilian Forest Law. The mapping was performed using remote sensing techniques and visual interpretation of the World View image, followed by the digitalization of the net of drainage and vegetation (natural and agricultural) at the AutoCad software with documents and field work. The study area has 2141.53 ha and the results demonstrated that the main crop is sugarcane with 546.34 ha, followed by 251.22 ha of pastures, 191.71 ha of perennial crops, 57.31 ha of Eucalyptus and 49.52 ha of onion, confirming the advance of sugarcane culture in the region. The region has 375.04 ha of areas of permanent preservation (APPs), and of this area it was found that only 72.17 ha $(19.24 \%)$ has arboreal vegetation or natural forest, and 302.87 ha of these areas need to be enriched and reforested with native vegetation from the region, according to the current legislation. The data of the area enable future proposals of models for environmental adaptation to the microbasin according to the current environmental legislation.
\end{abstract}

KEYWORDS: mapping, land use and occupation, vegetal coverage.

\section{ADEQUAÇÃO AMBIENTAL DA NASCENTE DA SUB-BACIA DO CÓRREGO RICO, MUNICÍPIO DE MONTE ALTO - SP}

RESUMO: Este trabalho teve como principal objetivo definir padrões fotográficos que representem o uso e a ocupação do solo da "cabeceira" de drenagem do Córrego Rico, localizada no Município de Monte Alto, Estado de São Paulo, para fins de adequação ambiental no que tange à legislação florestal brasileira. O mapeamento foi realizado utilizando técnicas de sensoriamento remoto e interpretação visual da imagem World View, seguida da digitalização da rede de drenagem e vegetações (naturais e agrícolas) no AutoCad, com auxílio de documentos e trabalho de campo. A área de estudo apresenta uma superfície de 2.141,53 ha, e os resultados permitiram constatar que a principal cultura é a cana-de-açúcar, com 546,34 ha, seguida de pastagens, com 251,22 ha, culturas perenes, com 191,71 ha, Eucalipto, com 57,31 ha, e a cebola, com 49,52 ha da área total, confirmando o avanço dos canaviais na região. A área possui 375,04 ha de áreas de preservação permanente (APPs), e desta superfície verificou-se que apenas 72,17 ha $(19,24 \%)$ encontram-se compostos por vegetação arbórea ou mata, e destas 302,87 ha precisam ser enriquecidos e reflorestados com vegetação nativa da região, de acordo com legislação vigente. Os dados de área possibilitam futuras propostas de modelos de adequação ambiental para a microbacia, de acordo com a legislação ambiental vigente.

PALAVRAS-CHAVE: mapeamento, uso e ocupação do solo, cobertura vegetal.

\footnotetext{
${ }^{1}$ Eng $^{\mathrm{a}}$ Agrônoma, Prof. Ass. Doutor, , Departamento de Engenharia Rural, Via de Acesso Prof. Paulo D. Castellane, s/n, Jaboticabal - SP, teresap@ fcav.unesp.br.

${ }^{2}$ Eng ${ }^{\underline{a}}$ Agrônoma, Mestre em Agronomia, Especialista Ambiental da Secretaria Estadual de Meio Ambiente, Centro Técnico Regional de Fiscalização de Ribeirão Preto.

${ }^{3}$ Eng ${ }^{0}$ Agrônomo, Funcionário do Banco do Brasil.

${ }^{4}$ Eng $^{\mathrm{o}}$ Agrônomo, Pesquisador do CEPeD UNIFAFIBE, Bebedouro -SP, galbi@ @cav.unesp.br.

${ }^{5}$ Eng $^{\mathrm{o}}$ Agrônomo, Doutor em Agronomia, Prefeitura Municipal de Jaboticabal.

${ }^{6}$ Eng ${ }^{\text {o }}$ Agrônomo , Prof. Titular, FCA/UNESP, Depto. de Engenharia Rural, Botucatu - SP.

Recebido pelo Conselho Editorial em: 30-8-2011
}

Aprovado pelo Conselho Editorial em: 21-11-2012 


\section{INTRODUCTION}

The environmental adaptation in hydrographic basins is important to comply with federal legislation of the Brazilian Constitution (BRAZIL, 1988). In Article $\mathrm{n}^{\circ}$ 225, this Constitution report that "Everyone has the right to an ecologically balanced environment and of common use and essential to a healthy quality of life, belonging to the Government and society the duty to defend and preserve it for present and future generations. "

The Forest Code, Federal Law no 4,771/65 (BRAZIL, 1965), defines that the area of permanent preservation (APP) is the area covered or not by native vegetation, with the environmental function of preserving water resources, landscape, geological stability, biodiversity, gene flow of fauna and flora, to protect soil and ensure the well being of human populations. This code also includes riparian forests in the category of areas of permanent preservation. Thus, all the natural vegetation, arboreal or not, present along the river banks and around sources and reservoirs should be preserved.

CONAMA Resolution $n^{\circ}$ 303/02 (BRAZIL, 2002), which also discuss about parameters, definitions and boundaries of APP, in the $3^{\text {rd }}$ Article, says that the APP consists in the area located:

I - in marginal strip, measured from the highest level in horizontal projection, with a minimum width of: thirty meters to the watercourse with less than ten feet wide;

II - around the source or waterhole, even if intermittent, with minimum radius of fifty meters in such a way that protects, in each case, the contributory hydrographic basin.

Thus, denoting the importance of the APPs, with the function of protecting the natural environment, this means that they are not appropriate areas for land use, and should be covered with native vegetation. The vegetal coverage in these areas will mitigate the effects of erosion and leaching of soils, contributing to regulation of water flow, reducing sedimentation of watercourse and reservoirs, bringing benefits to the fauna and flora.

For reforestation and recovery of degraded areas we have the Resolutions SMA 21 of 2001 and SMA 47 of 2003, and the most current, Resolution SMA 08 of 2008 (SMA, 2001, 2003, 2008), which fix the orientation for heterogeneous reforestation of degraded areas. In Resolution SMA of 2008 , there is an attachment that contains a list of the arboreal species and an indication of its natural biomes / ecosystems and ecological regions of the state of São Paulo (SMA, 2008).

The analysis of the land use and occupation in an area is the first step to guide an effective management regarding the means for the development of conservation practices, in common with farming practices, and economic development with less impact to the environment. OLIVEIRA et al. (2008); DELALIBERA et al. (2008) and NASCIMENTO et al. (2006), conducted studies aiming to develop maps of land use based on satellite images to identify conflicts of uses, having as reference the Brazilian Forest Law. The surveys were developed around the National Park of Caparaó in the state of Minas Gerais, in Ponta Grossa - in the state of Paraná and the hydrographic basin of the Alegre River, located in the southern of the state of Espírito Santo. The geoprocessing resources were the basis for mapping classes of land use, to contemplate the requirements of Areas of Permanent Preservation, regarding to the occurrence of sources and riparian vegetation.

VALLE JUNIOR et al. (2010) report that a hydrographic basin is geographically a system defined with great diversity of environments where they develop different economic activities, which have a direct effect on vegetation, soils, topography, water bodies and biodiversity in general.

This study aimed to set photographic standards representing the evaluation of the use and occupation of the source of Rico Stream, located in Monte Alto - São Paulo (SP), Brazil. The information obtained will be the basis for a database on territorial unit of hydrographic basin, for purposes of environmental adaptation regarding the Brazilian Forest Law. 


\section{MATERIALS AND METHODS}

The study was performed at the spring drainage of the Rico Stream subbasin, and it was considered as the territorial unit of work, the main set of sources of the stream or region of higher altitude. The area has an extension of $2,141.53$ ha, corresponding to $3.95 \%$ of the hydrographic basin of Rico Stream and located between the geographical coordinates of latitude $21^{\circ} 16^{\prime} 04^{\prime \prime} \mathrm{S}$ and $21^{\circ} 20^{\prime} 49^{\prime \prime} \mathrm{S}$ and longitude $48^{\circ} 27^{\prime} 42^{\prime \prime} \mathrm{W}$ Gr. and $48^{\circ} 31^{\prime} 19^{\prime \prime} \mathrm{W}$ Gr., whose source begins at the Rico Stream including its route until the junction with the Glória Farm Stream, in Monte Alto - SP.

The main soil types found in the studied area are the Red-Yellow Argisols (PVA3), the RedYellow Argisols (PVA4) and Litholic Neosols (EMBRAPA, 1999). The climate, according to Köeppen, is classified as humid mesothermal of hot summer and dry winter (Cwa type), and the annual rainfall ranges from $1,100 \mathrm{~mm}$ to $1,700 \mathrm{~mm}$. The average annual relative humidity is approximately $71 \%$, occurring concentration of rainfall during the period of October to March and the dryer season extends from April to September. The predominant forest formation type consists of the semi-deciduous forest.

The study was based on visual analysis of images taken by the Panchromatic Sensor, installed aboard the Satellite WorldView 1, dated in October 2005, at scales of approximately 1:15,000 in Panchromatic band and quadrants P001, P002 and P003 on the current area. The topographic maps published by the Brazilian Institute of Geography and Statistics (Instituto Brasileiro de Geografia e Estatística - IBGE, 1971), at scale 1:50,000, vertical equidistance between curves of 20m level were used as auxiliary in the delimitation of various characteristics of the study area and mainly as a point of planialtimetric support of drainage net and the location of the hydrographic microbasin. The sheets used were IBGE topographical maps, at scale 1:50,000, the areas surrounding the maps in question are: Taiúva (SF-22-X-III-1), Pirangi (SF-22-X-D-II-2) Jaboticabal (SF-22-X-D-III-3) and Taquaritinga (SF-22-X-D-II-4).

As equipments, it was used computer system compatible for image analysis. The maps were drawn with georeferenced control points for mobile and fixed receivers TRIMBLE GPS and tuned to American NAVSTAR artificial satellites. The Mark of Reference (base station) for data collection with GPS receivers was the geodesic mark of the Department of Rural Engineering of FCAV/UNESP.

For the digitalization, junction of the maps and graphical representation of the area it was used the AutoCad2008 program, which is a graphic design software, having vector files. For processing the data collected in the field for georeferencing it was used the Program GPSurvey. The details of this study were transferred to the base map, establishing the geographical distribution and general representation of the area.

For the preparation of the map of use/occupation of the area with remote sensing data visually interpreted and to extract the information of the image was determine the elements of the image recognition. The methodology was based on the analysis of visual patterns identified on aerial photographs, which were: shape, size, shadow, tone/color, pattern, texture, location and aspects relation, adapted from the studies by AMARAL (1998) and ENDRES (2006). These characteristics are summarized in Table 1. 
TABLE 1. Photographic patterns of land use and occupation of the spring drainage of the Rico Stream, Monte Alto-SP.

\begin{tabular}{|c|c|c|c|c|c|c|c|c|c|c|}
\hline \multirow[b]{2}{*}{$\begin{array}{c}\text { Photographic } \\
\text { pattern }\end{array}$} & \multicolumn{10}{|c|}{ Land use and occupation } \\
\hline & $\begin{array}{l}\text { Annual } \\
\text { Culture } \\
\text { (Onion) }\end{array}$ & $\begin{array}{c}\text { Annual Culture } \\
\text { (Sugarcane) }\end{array}$ & $\begin{array}{l}\text { Perennial } \\
\text { Culture }\end{array}$ & $\begin{array}{c}\text { Vegetation } \\
\text { or forest }\end{array}$ & $\begin{array}{l}\text { Clean Field } \\
\text { or pasture }\end{array}$ & $\begin{array}{c}\text { Eucalyptus } \\
\text { Culture }\end{array}$ & $\begin{array}{l}\text { Cultivated } \\
\text { Plain }\end{array}$ & $\begin{array}{l}\text { Re- } \\
\text { forestation }\end{array}$ & Dams & $\begin{array}{l}\text { Other uses or } \\
\text { non- } \\
\text { individualized } \\
\text { Cultures }\end{array}$ \\
\hline Texture & Very thin & Velvety thin & Granular & Rough & $\begin{array}{l}\text { Granular and } \\
\text { very thin }\end{array}$ & $\begin{array}{l}\text { Thin and } \\
\text { Very thin }\end{array}$ & $\begin{array}{l}\text { Medium to } \\
\text { thin velvety }\end{array}$ & Rugose & Very thin & Very thin \\
\hline Appearance & Low & $\begin{array}{c}\text { Herbaceous and } \\
\text { shrubby }\end{array}$ & $\begin{array}{l}\text { Shrubby or } \\
\text { arborous }\end{array}$ & $\begin{array}{c}\text { Shrubby or } \\
\text { arborous }\end{array}$ & Creeper & Arborous & $\begin{array}{l}\text { Creeper and } \\
\text { shrubby }\end{array}$ & Arborous & - & Herbaceous \\
\hline Tonality & $\begin{array}{l}\text { Medium } \\
\text { green }\end{array}$ & $\begin{array}{l}\text { Light to } \\
\text { medium green }\end{array}$ & $\begin{array}{l}\text { Uniform } \\
\text { dark green }\end{array}$ & $\begin{array}{c}\text { Uniform } \\
\text { dark green }\end{array}$ & $\begin{array}{l}\text { Medium and } \\
\text { light green }\end{array}$ & Dark green & $\begin{array}{l}\text { Medium } \\
\text { and light } \\
\text { green }\end{array}$ & Varied & Dark grey & Light green \\
\hline Roof & Plain & $\begin{array}{c}\text { Continuous and } \\
\text { homogeneous } \\
\text { plain }\end{array}$ & Plain & Wavy & $\begin{array}{c}\text { Isolated } \\
\text { arborous } \\
\text { appearance }\end{array}$ & Plain & $\begin{array}{l}\text { Plain and } \\
\text { slightly } \\
\text { wavy }\end{array}$ & $\begin{array}{l}\text { Non- } \\
\text { uniform }\end{array}$ & Uniform & Plain \\
\hline Image & & & & & & & & & & \\
\hline
\end{tabular}

Adapted data from the studies developed by AMARAL (1998) and ENDRES (2006).

As a result of visual interpretation done on aerial photographs and cartographic documents, it was identified the following geoindicators: hydrographic net, topographic dividers and plant communities (natural and agricultural), and later it was elaborated the maps regarding the land use/occupation, drainage net and environmental dynamics.

The map of the land use/occupation was drawn by the division of plant formations in the collection of images obtained, dated in 2005, based and adapted on the map legend of use and occupation of the Book of Basic Information for Environmental Planning: City of Jaboticabal (PISSARRA et al., 2009), obtained at the Photointerpretation Laboratory of the Department of Rural Engineering of the FCAV/UNESP.

By counting the cells belonging to each category were measured the areas for each type of use, establishing the percentage of occupation. The measurements of the areas were performed using the AutoCad program, where the areas of each polygon of different uses and occupations were measured, being adopted as unit of measure the hectare (ha).

\section{RESULTS AND DISCUSSION}

As a result of the analysis of images in cartographic documents was identified the hydrographic net and the natural and agricultural plant communities (Figures 1 and 2). 


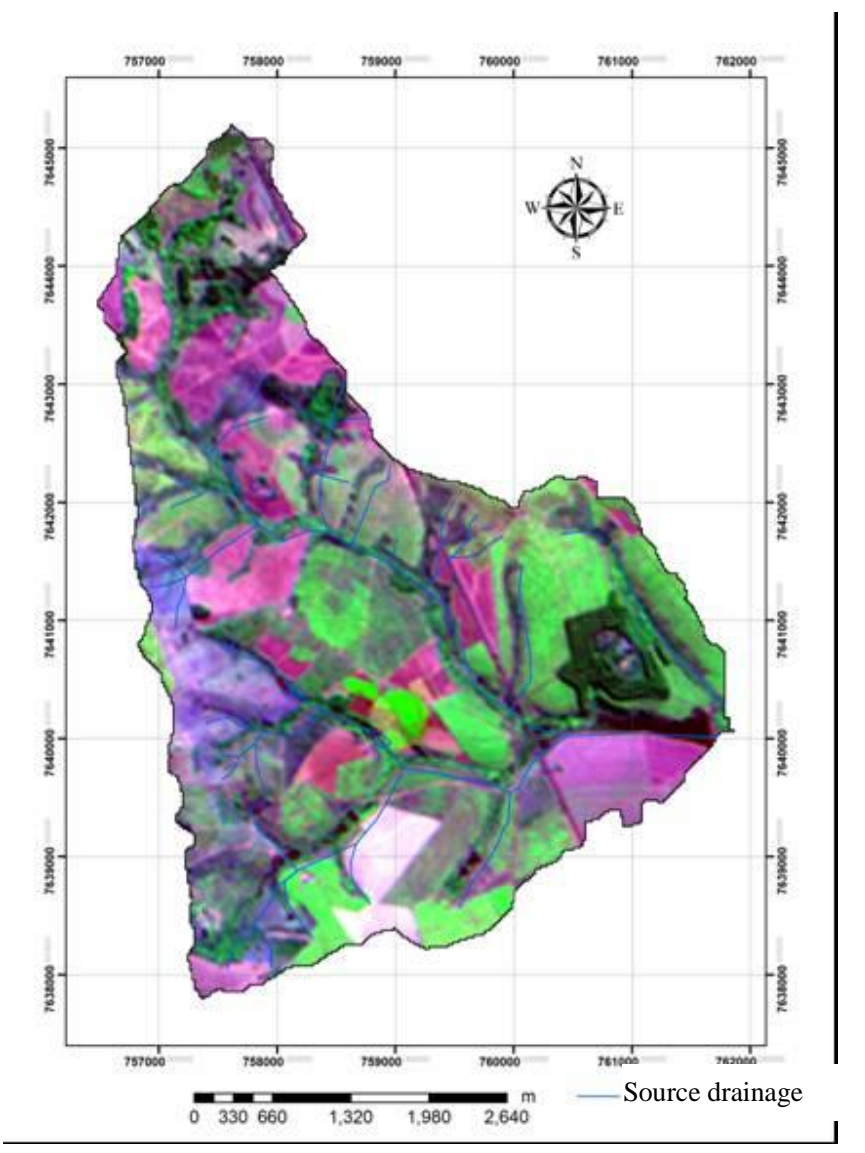

FIGURE 1. Map of the drainage net of the source of the hydrographic basin of Rico Stream, Monte Alto - SP, Brazil.

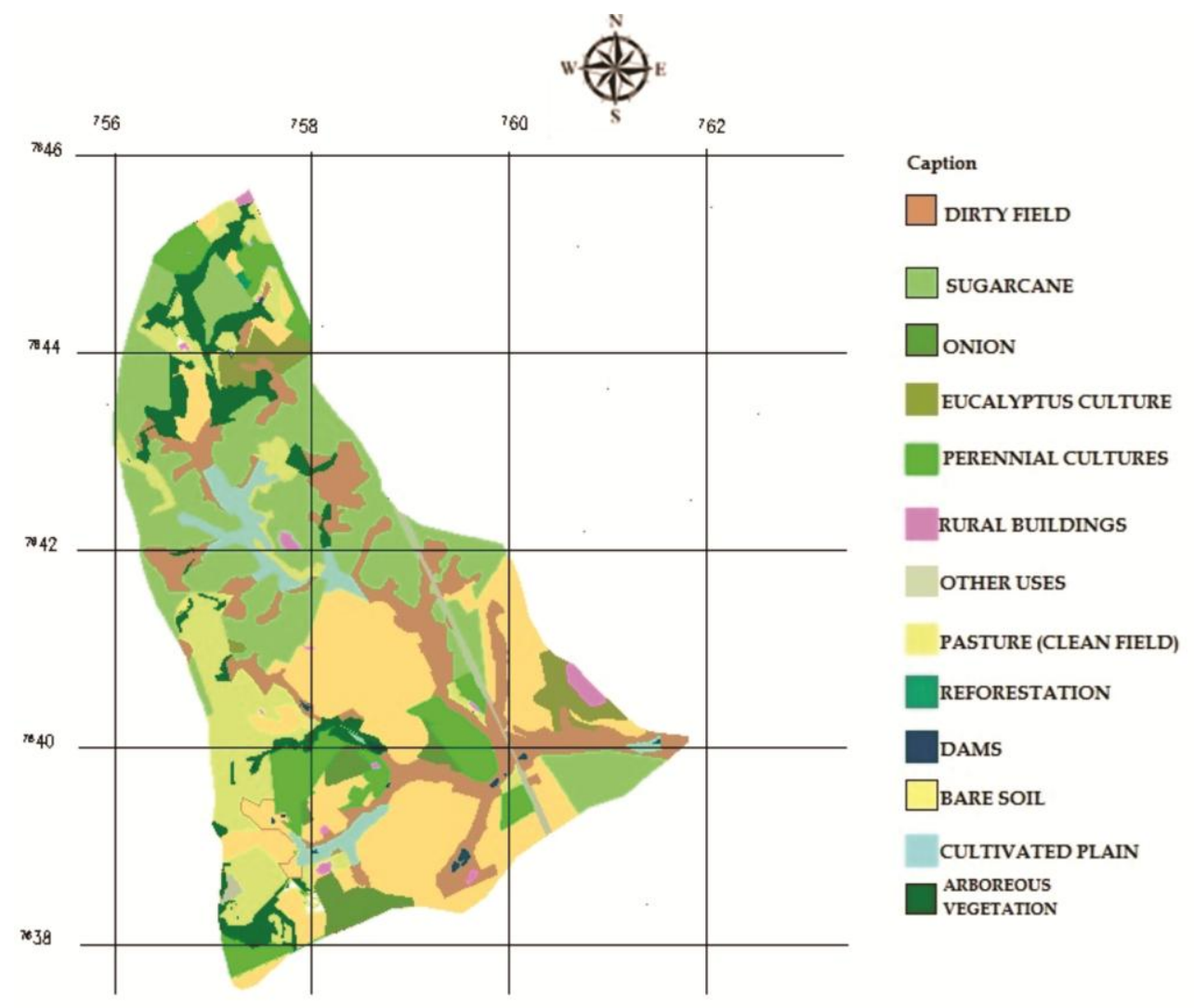

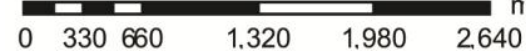

FIGURE 2. Map of the land use and occupation of the spring of the hydrographic basin of Rico Stream - SP/2005. 
In Figure 1 we can observe that the area presents a net of drainage branched with minor extensions, forming a region with a number of about 70 sources. This fact proves that the region of the city of Monte Alto - SP, present an interesting geological region of topographic divide, and have an immeasurable wealth of water, which supplies a large portion of the population and various cities, reinforcing the importance of preserving these water sources in the area and the city as a whole, supporting the study of PISSARRA et al. (2009).

The grazing areas (Figure 2) comprises the areas of clean pasture-field, whose primary difference from other analyzed coverage is the identification of the creeping appearance of the plant community installed, even when conditions of drained cultivated plain without identification of channel. In dirty field, the presence of irregular and sparse herbaceous vegetation is intercepted as abandonment of pasture area. The areas of clean field match with the presence of pasture in the form of culture, introducing granular texture much thinner and uniform than the areas of dirty field. These areas are predominantly located along the drainage net.

The cultures present defined geometric shapes, in strips and variable aspect according to the age. Perennial cultures found in the hydrographic basin, such as orchards of guava, mango and citrus have regular geometric shape and highlighted contour. The structure of plants is arranged in defined, regular and individualized alignments, and rough to medium texture and dark green tonality (Figure 2).

The other cultures have geometric shape with expression of varied contour, with low occurrence of carriers, having disordered structure and varied tonalities depending on the time of development. Regarding to the aspects, it was identified lines of level and terrace and the presence of geometric shapes that characterize the circular central pivot usually present in the onion culture, as noted in the field (Figure 2). The culture of sugarcane is predominant. This culture is distributed in relatively large areas, cut by carriers, with at least two stages of development, regular geometric shapes, flat, continuous and homogeneous roof. The grown sugarcane presented rougher texture than the new sugarcane with tonality of medium to light green, respectively. The structure was formed by the set of plots delimited by carriers which stand out to the associated aspects (Figure 2).

The areas with infrastructure called rural buildings correspond to houses, sheds, barns and other farm buildings, with their surroundings with trees or clean. The dam areas correspond to the limits of the water surface along the drainage net, where there was the extremity with dam or in pond form (Figure 2).

TABLE 2. Distribution of the main land uses/occupation of the hydrographic basin of Rico Stream, in Monte Alto - SP/2005.

\begin{tabular}{lcc}
\hline Use and occupation & Area (ha) & Percentage of the total area (\%) \\
\hline Bare soil & 493.32 & 23 \\
Arborous vegetation or forest & 151.75 & 7 \\
Dirty Field & 289.46 & 14 \\
Clean Field or pasture & 251.22 & 12 \\
Perennial cultures (mango, guava and citrus) & 191.71 & 8 \\
Eucalyptus & 57.31 & 3 \\
Sugarcane & 546.34 & 26 \\
Annual cultures (Onion) & 49.62 & 2 \\
Cultivated plain & 63.92 & 3 \\
Reforestation & 1.22 & - \\
Dams & 6.54 & - \\
Rural buildings & 17.34 & 1 \\
Other uses and non-individualized cultures & 21.79 & 1 \\
\hline Total & $2,141.53$ & 100 \\
\hline
\end{tabular}




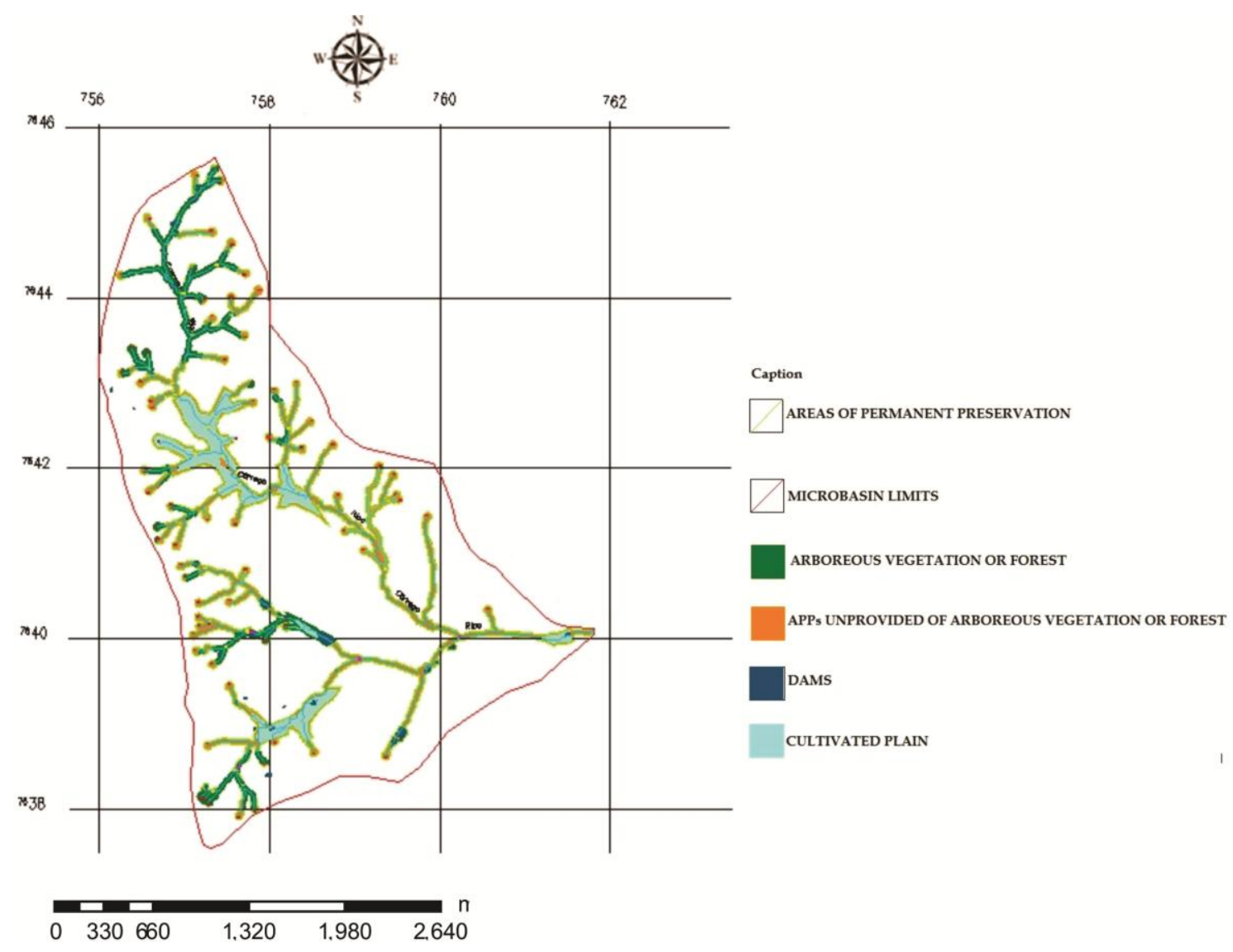

FIGURE 3. Map of the environmental dynamic of the spring of drainage of the hydrographic microbasin of Rico Stream - SP/2005.

When preparing the legend of Figure 2 and 3 it was used information from the visual interpretation of the images, the areas of arborous vegetation or forest comprise the areas of reminiscent forest, characterized by irregular borders and variable aspect with formation dominated by arboreal elements, composed of three layers of vegetation, with rough texture and dark green color.

Generally, these formations were found near watercourses or near rivers and in areas with more accentuated slopes, in areas where the topography and soil type limit the use of agricultural cultures.

The global set of data presented (Table 2 and Figure 2) confirms that the cultivation of sugarcane is the main form of land use in the spring of the hydrographic microbasin, with $26 \%$ of the total area, over the citrus, guava and mango orchards, with $9 \%$, and onion with only $2 \%$, cultures that previously occupied the largest area of the subbasin.

The permanent crops presented higher expression in more irregular areas, associated with the presence of Argisols, and the onion and sugarcane plantations were concentrated in flatter areas. In the analyzed period, we denote the advantage presented by the economic culture of sugarcane. With the proximity of some sugar and alcohol mills, the sugarcane culture is occupying the space that was once occupied by other crops, especially perennial cultures such as citrus, guava and mango and annual traditional culture of the region, the onion.

Another important fact is the low percentage of reforestation observed in the area, which is of 1.46 ha. It is noteworthy that there is 375.04 ha of areas of permanent preservation and 302.87 ha of these are not preserved, i.e. it was analyzed only 72.17 ha $(19.24 \%$ of the areas of permanent preservation) is composed of arborous vegetation or forest. 
The predominantly more irregular relief occurs in Argisols PVA3 and PVA4 (wavy to strong wavy relief) and the same was observed by PISSARRA (2006). The spring microbasins have a higher degree of evolution of the hydrographic basin. In the region of the springs of drainage are all the microbasins of 2 nd order of magnitude likely to transport material on a larger scale, tending to lower resistance to removal of the surface mantle, with more intense erosion process. The complexity is exacerbated in the subbasins of the sources of the Tijuco and Gambá Streams near the city of Monte Alto and source of Rico Stream. These data reinforce the importance of preserving the APP and the need for environmental adaptation of the spring of drainage, avoiding negative effects of human disturbance, such as erosion, siltation of rivers and other problems on water and soil quality of the area.

Although they are areas of permanent preservation, protected by State and Federal legislation (OLIVEIRA et al., 2008; DELALIBERA et al., 2008 and NASCIMENTO et al., 2006), the riparian forests, cultivated plain areas and forest fragments of slope are suffering significant changes. The intense and disordered devastations are leading to the disappearance of several species of ecological and commercial importance, with serious impairment of their genetic potential.

As noted, the panorama of areas of forests is critical, including forests, cerrados and fields. When there is change in this scenario and there is an environmental analysis of previously degraded area recovery, it is necessary to highlight and ennoble this fact (VALLE JUNIOR et al., 2010).

The manual survey and mapping has high accuracy due to the rigorous detailing adopted in the data survey of land use and occupation, drainage net and arboreal vegetation in APPs, providing maximum approximation of the reality of the area, and therefore it is perfectly suited for small areas and regions with predominantly small farmers because it allows proposed models of adaptation economically viable.

The data concerning the land use and occupation, drainage net and environmental dynamics of the hydrographic microbasin of the Rico Stream enable to conclude that there is a real need to preserve the area in question not only for its rich water resources, but also because of the aggravating factors as: strongly marked relief, soil type susceptible to erosion and low percentage of vegetation in areas of permanent preservation. Thus, the study and analysis of the spring area of the microbasin have the data for future models of proposed environmental adaptation in accordance with the current environmental legislation.

\title{
CONCLUSIONS
}

The study area present a surface of 2,141.53 ha and the results allowed to prove that the main culture is of sugarcane with 546.34 ha, followed by pastures with 251.22 ha, perennial cultures with 191.71 ha, Eucalyptus with 57.31 ha and onion with 49.52 ha of the total area. There are 375.04 ha of areas of permanent preservation. Only 72.17 ha (19.24\% of the areas of permanent preservation) are composed by arborous vegetation or forest, and of those, 302.87 ha need to be enriched and reforested with native vegetation of the region, according to the current legislation.

\section{REFERENCES}

\begin{abstract}
AMARAL, L.A. Estudo por fotointerpretação da influência do tipo de ocupação do solo na manifestação da erosão acelerada no Município de Araraquara, SP. 1998. Monografia (Trabalho de Graduação em Agronomia) - Faculdade de Ciências Agrárias e Veterinárias, Universidade Estadual Paulista, Jaboticabal, 1998.
\end{abstract}

BRASIL. Código Florestal, na Lei Federal nº 4.771/65, 1965.

BRASIL. Constituição da República Federativa do Brasil, 1988.

BRASIL. Ministério do Meio Ambiente. Resolução CONAMA nº 303, de 20 de março de 2002. 
DELALIBERA, H. C.; WEIRICH NETO, P. H.; LOPES, A. R. C.; ROCHA, C. H. Alocação de reserva legal em propriedades rurais: do cartesiano ao holístico. Revista Brasileira de Engenharia Agrícola e Ambiental, Campina Grande, v.12, n.3, p.286-292, 2008.

EMBRAPA. EMPRESA BRASILEIRA DE PESQUISA AGROPECUÁRIA. Centro Nacional de Pesquisa de Solos. Sistema brasileiro de classificação de solos. Brasília: EMBRAPA - Produção de Informação; Rio de Janeiro: Embrapa Solos, 1999. 412 p.

ENDRES, P. F.; PISSARRA, T. C. T.; BORGES, M. J.; POLITANO, W. Quantificação das classes de erosão por tipo de uso do solo no município de Franca - SP. Engenharia Agrícola, Jaboticabal, v.26, n.1, p.200-207, 2006.

IBGE. INSTITUTO BRASILEIRO DE GEOGRAFIA E ESTATÍSTICA. Departamento de Cartografia. Carta do Brasil: Jaboticabal e Taquaritinga. Escala 1:50.000. São Paulo: Instituto, 1971.

NASCIMENTO, M. C. do; SOARES, V. P.; RIBEIRO, C. A. A. S.; SILVA, E. Mapeamento dos fragmentos de vegetação florestal nativa da bacia hidrográfica do rio Alegre, Espírito Santo, a partir de imagens do satélite IKONOS II. Revista Árvore, Viçosa, v.30, n.3, p.389-398, 2006.

OLIVEIRA, F. S. de. Identificação de conflito de uso da terra em áreas de preservação permanente no entorno do parque nacional do Caparaó, Estado de Minas Gerais. Revista Árvore, Viçosa, v.32, n.5, p.899-908, 2008.

PISSARA, T. C. T.; BORGES, M. J.; GALBIATTI, J. A.; RODRIGUES, F. M.; POLITANO, W. Morphometric analysis of the Córrego Rico watershed, Jaboticabal - SP, Brazil. Científica, Jaboticabal, v.34, n.2, p.170-177, 2006.

PISSARRA, T. C. T (Coord.). Informações básicas para o planejamento ambiental: Município de Jaboticabal/Secretaria Municipal de Agricultura, Abastecimento e Meio Ambiente de Jaboticabal. Jaboticabal. Funep, 2009.

SMA. SECRETARIA DO MEIO AMBIENTE. Legislação Ambiental. Disponível em <http://www.ambiente.sp.gov.br/contAmbientalLegislacaoAmbiental.php> Acesso em: 6 nov. 2010.

VALLE JUNIOR, R. F. do; PISSARRA, T.C.T.; PASSOS, A. de O.; RAMOS, T.G.; ABDALA, V.L. Diagnóstico das áreas de preservação permanente na bacia hidrográfica do Rio Tijuco, Ituiutaba - MG, utilizando tecnologia SIG. Engenharia Agrícola, Jaboticabal, v.30, n.3, p.495-503, 2010 . 